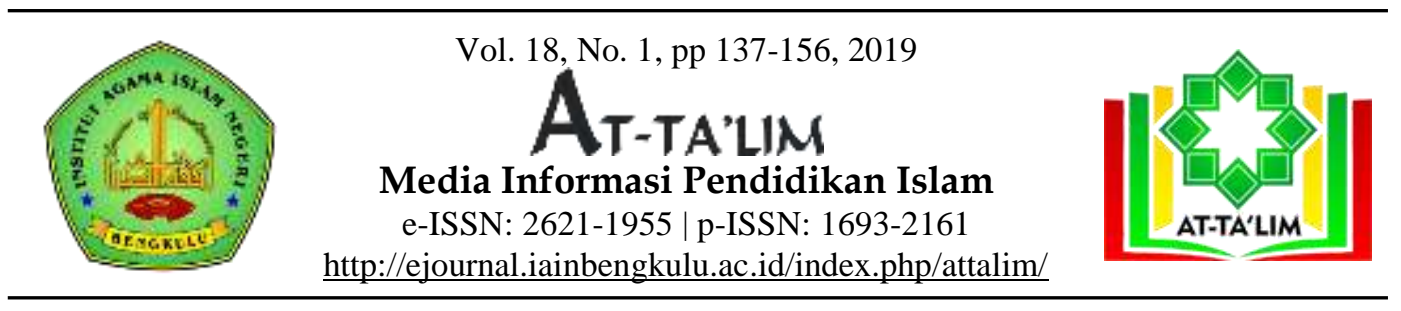

\title{
Pengaruh Model Pembelajaran ARCS (ATTENTION, RELEVANCE, CONFIDENCE, SATISFACTION) DAN MOTIVASI TERHADAP HASIL BELAJAR IPS SISWA KELAS V SD NEGERI 75 KOTA BENGKULU
}

\author{
SUKARNO' 1 , SALAMAH2 \\ ${ }^{1}$ upma.sukarno@gmail.com \\ ${ }^{2}$ salamah@iainbengkulu.ac.id \\ 1,2 Dosen Fakultas Tarbiyah dan Tadris \\ Institut Agama Islam Negeri (IAIN) Bengkulu \\ Jl. Raden Fatah Kota Bengkulu, Indonesia.
}

Abstract: Effect of ARCS Learning Model (Attention, Relevance, Confidence, Satisfaction) and Motivation on Social Sciences Learning Outcomes of Grade V Students of SD Negeri 75 Kota Bengkulu. This study aimed to determine the differences in student learning outcomes using the ARCS learning model with conventional learning models in class V of SD Negeri 75 Kota Bengkulu, differences in learning outcomes from groups of students with high learning motivation levels using the ARCS learning model with conventional learning models in class V SD Negeri 75 Kota Bengkulu, differences in learning outcomes from groups of students with low learning motivation levels using the ARCS learning model with conventional learning models in class V of SD Negeri 75 Kota Bengkulu, and interaction of learning models with motivation towards learning outcomes of fifth grade students at SD Negeri Kota Bengkulu. This study uses a quantitative approach with a type of quasi-experimental research. The subjects of this study were 75 elementary school students in the city of Bengkulu, totaling 62 students. Data collection is done by using tests and questionnaires with research design using factorial 2X2. Data analysis techniques, using the " $t$ " test and " $F$ " test The results showed 1) Overall there are differences between student learning outcomes taught by using the ARCS learning model with conventional learning models IPS subjects class V SD Negeri Bengkulu city. By showing the test results "t" Sig. 0,000 (2-tailed) <0.050. 2) there are differences in learning outcomes of students with high learning motivation between those taught by using the ARCS learning model with conventional learning models on social studies subjects in class V of SD Negeri 75 Kota Bengkulu. By showing the results of the " $t$ " test sig value of $0.010<$ alpha $5 \%$ (0.050). 3) there is no difference in learning outcomes of students with low learning motivation between those taught by using the ARCS learning model with conventional learning models on social studies subjects in class V 75 SD Negeri Bengkulu city. With the results of the " $t$ " test, the sig value is $0.235>$ alpha $5 \%(0.050)$. 4) There is no interaction between the learning model and learning motivation towards student learning outcomes in social studies subjects in grade 
$\mathrm{V}$ in SD Negeri 75 Kota Bengkulu. By showing the results of the "F" test sig. $0.490>0.050$.

Keywords: ARCS learning, motivation, and learning outcomes

Abstrak: Pengaruh Model Pembelajaran ARCS (Attention, Relevance, Confidence, Satisfaction.) dan Motivasi Terhadap Hasil Belajar IPS Siswa Kelas $V$ SD Negeri 75 Kota Bengkulu. Penelitian ini bertujuan Untuk mengetahui perbedaan hasil belajar siswa dengan menggunakan model pembelajaran ARCS dengan model pembelajaran konvensional pada kelas V SD Negeri 75 Kota Bengkulu, perbedaan hasil belajar dari kelompok siswa yang tingkat motivasi belajar tinggi dengan menggunakan model pembelajaran ARCS dengan model pembelajaran konvensional pada kelas $V S D$ Negeri 75 Kota Bengkulu, perbedaan hasil belajar dari kelompok siswa yang tingkat motivasi belajar rendah dengan menggunakan model pembelajaran ARCS dengan model pembelajaran konvensional pada kelas V SD Negeri 75 Kota Bengkulu, dan interaksi model pembelajaran dengan motivasi terhadap hasil belajar siswa kelas $V$ SD Negeri Kota Bengkulu. Penelitian ini menggunakan pendekatan Kuantitatif dengan jenis penelitian quasi eksperimen. Subjek penelitian ini adalah siswa SD Negeri 75 kota Bengkulu yang berjumlah 62 orang siswa. Pengumpulan data dilakukan dengan menggunakan tes dan angket dengan desain penelitian menggunakan factorial 2X2. Teknik analisis data, menggunakan uji " $t$ " dan uji " $F$ " Hasil penelitian menunjukkan 1) Secara keseluruhan terdapat perbedaan hasil belajar siswa antara yang diajar dengan menggunakan model pembelajaran ARCS dengan model pembelajaran konvensional mata pelajaran IPS kelas $V$ SD Negeri kota Bengkulu. Dengan ditunjukkan hasil uji " $t$ " Nilai Sig. 0,000 (2tailed) $<0.050$. 2) terdapat perbedaan hasil belajar siswa dengan motivasi belajar tinggi antara yang diajar dengan menggunakan model pembelajaran ARCS dengan model pembelajaran konvensional pada mata pelajaran IPS kelas V SD Negeri 75 kota Bengkulu. Dengan ditunjukkan hasil uji " $t$ " Nilai sig sebesar $0.010<$ alpha 5\% $(0,050)$. 3) tidak terdapat perbedaan hasil belajar siswa dengan motivasi belajar rendah antara yang diajar dengan menggunakan model pembelajaran ARCS dengan model pembelajaran konvensional pada mata pelajaran IPS kelas V SD Negeri 75 kota Bengkulu. Dengan ditunjukkan hasil uji " $t$ " Nilai sig sebesar $0.235>$ alpha 5\% $(0,050)$. 4) Tidak terdapat interaksi antara model pembelajaran dengan motivasi belajar terhadap hasil belajar siswa pada mata pelajaran IPS kelas V SD Negeri 75 kota Bengkulu. Dengan ditunjukkan hasil uji " $F$ " sig. $0.490>0.050$..

Kata Kunci: Pembelajaran ARCS , motivasi, dan hasil belajar

To cite this article:

Sukarno (2019). Pengaruh Model Pembelajaran ARCS (Attention, Relevance, Confidence, Satisfaction.) dan Motivasi Terhadap Hasil Belajar IPS Siswa Kelas V SD Negeri 75 Kota Bengkulu. At-Ta'lim: Media Informasi Pendidikan Islam, 18(1), 137-156.

\section{A. INTRODUCTION / PENDAHULUAN}

Pendidikan adalah usaha manusia untuk mencerdaskan dan membina kepribadiannya sesuai dengan nilai-nilai dalam masyarakat dan 
kebudayaan. Dalam perkembangannya, istilah pendidikan atau paedagogie berarti bimbingan atau pertolongan yang diberikan dengan sengaja oleh orang dewasa agar ia menjadi dewasa. Selanjutnya, pendidikan diartikan sebagai usaha yang dijalankan oleh seseorang atau kelompok orang lain agar menjadi dewasa atau mencapai tingkat hidup atau penghidupan yang lebih tinggi dalam arti mental (Hasbullah, 2009).

Pendidikan menentukan model manusia yang akan dihasilkan serta pendidikan juga memberikan konstribusi yang sangat besar dalam kemajuan suatu bangsa dan merupakan sarana dalam membangun karakter bangsa (Nation Character Building). Maka hasil pendidikan menjadikan masyarakat yang cerdas, bertaqwa akan memberi nuansa kehidupan yang cerdas, kemandirian, kreativitas, kesejahteraan dan berdaulat. Melalui pendidikan, bangsa Indonesia dapat membebaskan dari krisis multidimensi yang berkepanjangan dan dapat membebaskan masyarakat dari kemiskinan dan keterpuruk.

Standar nasional pendidikan terdiri atas standar isi, proses, kopetensi lulusan, tenaga kependidikan, sarana dan prasarana, pengelolaan, pembiayaan dan penilaian pendidikan. Dua dari delapan standar nasional pendidikan tersebut, yaitu Standar Isi (SI) dan Standar Kopetensi Lulusan (SKL) merupakan acuan utama bagi satuan pendidikan dalam mengembangkan kurikulum (Ahmad, 2011).

Pembelajaran IPS secara khusus sebagai mana tujuan pendidikan secara umum menjelaskan bahwa: Diharapkan dapat memberikan pengetahuan (kognitif), yang merupakan tujuan utama dari pembelajaran. Jenis pengetahuan yang dimaksud adalah pengetahuan dasar dari perinsip dan konsep yang bermanfaat untuk kehidupan sehari-hari. Pengetahuan secara garis besar tentang fakta yang ada dialam untuk dapat memahami dan memperdalam lebih lanjut, dan melihat adanya keterangan serta keteraturannya. Disamping hal itu, pembelajaran IPS diharapkan pula memberikan keterampilan (psikomotorik), kemampuan 
sikap ilmiah (afektif), pemahaman, kebiasaan dan apresiasi. Didalam mencari jawaban terhadap suatu permasalahan. Karena ciri-ciri tersebut yang membedakan dengan pembelajaran lainnya (Trianto, 2010)

Kenyataan yang ditemukan di sekolah masih belum sesuai dengan apa yang diharapkan, pembelajaran IPS masih banyak menyimpan permasalahan. Permasalahan yang ada antara lain masih belum optimalnya inovasi pembelajaran yang digunakan, sehingga belum mampu mengoptimalkan motivasi diri siswa. Guru enggan untuk mengubah gaya mengajar dan lebih banyak untuk menceramahi siswa. Permasalahan lain yang paling klasik adalah kurangnya sarana pendukung termasuk media untuk pembelajaran.

Ilmu Pengetahuan Sosial (IPS) merupakan salah satu mata pelajaran yang diberikan mulai dari SD/MI/SDLB sampai SMP/MTs/SMPLB. IPS mengkaji seperangkat peristiwa, fakta, konsep dan generalisasi yang berkaitan dengan isu sosial. Pada jenjang SD/MI mata pelajaran IPS memuat materi Geografi, Sejarah, Sosiologi, dan Ekonomi. Dewasa ini Pembelajaran Pendidikan IPS dihadapkan pada tantangan untuk mempersiapkan manusia Indonesia yang mampu memerankan diri dalam kehidupan dunia modern. Maka melalui pendidikan IPS, diharapkan lahir manusia - manusia Indonesia yang mempunyai jiwa dan semangat yang tangguh dalam mendukung dan melaksanakan pembangunan nasional sesuai dengan tujuan pendidikan nasional (W., 2010)

Permasalahan tersebut tampaknya juga terjadi pada Sekolah Dasar/Madrasah Ibtida'iyah, khusus untuk pengelolaan pembelajaran di SD Negeri 75 kota Bengkulu. Hal ini diperkuat juga oleh hasil observasi awal yang dilakukan pada SD Negeri 75 telah memiliki guru yang kompeten dalam bidangnya, karena untuk menjadi guru di SD Negeri 75 harus melalui seleksi yang ketat, baik kompetensi dibidang profesional, pedegogik, personal, maupu social. Secara umum sekolah telah 
melaksanakn proses pembelajaran dengan baik yang disertai dengan kedisiplinan yang tinggi oleh para gurunya, begitu juga waktu pembelajaran telah diatur dengan sedemikian rupa, sehingga para siswa mampu bertahan sampai dengan jam 13.00 baru pulang dengan selalu didampingi oleh para pendidiknya. Sekolah Dasar Negeri 75 Memiliki kelas yang baik dan bersih dan cukup nyaman untuk digunakan dalam pembelajaran.

Hasil studi awal melalui wawancara dari beberapa guru ditemukan adanya pembelajaran yang seragam, karena adanya tuntutan dalam pemenuhan / target, kurikulum yang diterapkan pada SD Negeri 75, sehingga guru harus berusaha menghabiskan materi tanpa peduli dengan penerapan model pembelajaran, yang selama ini masih adanya kecenderungan menggunakan model pembelajaran klasikal, baik dalam tatanan tempat duduk maupu dalam proses interaksi, sehingga motivasi diri siswa yang menunjukkan berbagai perbedaan ini terabaikan.

Berdasarkan kondisi-kondisi tersebut, maka dapat diketahui bahwa permasalahan mendasar yang dialami guru dalam melaksanakan proses pembelajaran IPS adalah pengelolaan pembelajaran yang kurang optimal. Oleh sebab itu guru diharapkan mampu menerapkan model pembelajaran yang bermakna bagi siswa agar siswa merasakan bahwa hal-hal yang dipelajarinya bermakna baginya. Untuk itu penulis mencoba untuk mengkaji lebih jauh tentang model pembelajaran dengan memperhatikan motivasi belajar dan hasil belajar. ARCS merupakan akronim dari: Attention, Relevance, Confidence, Satisfaction. ARCS sebagai model pendekatan dalam pembelajaran dikembangkan oleh Keller dan Kopp (1987) sebagai jawaban pertanyaan "bagaimana merancang pembelajaran yang dapat mempengaruhi motivasi belajar dan hasil belajar". Model ARCS berakar pada banyak teori dan konsep motivasi, khasnya adalah teori harapan-nilai (expectancy-value). 
model pembelajaran ARCS terdiri dari empat komponen. Keempat komponen model pembelajaran ARCS tersebut yaitu sebagai berikut:

A. Attention (perhatian)

Konsentrasi/perasaan siswa dan minat dalam belajar bisa dilihat dari siswa yang perasaannya senang akan membantu dalam konsentrasi belajarnya dan sebaliknya siswa dalam kondisi tidak senang maka akan kurang berminat dalam belajarnya dan mengalami kesulitan untuk berkonsentrasi terhadap pelajaran yang sedang berlangsung. .

Menurut Keller (1987) strategi untuk menjaga dan meningkatkan perhatian siswa yaitu sebagai berikut:

1. Gunakan metode penyampaian dalam proes pembelajaran yang bervariasi (kelas, diskusi kelompok, bermain peran, simulasi, curah pendapat, demontrasi, studi kasus).

2. Gunakan media (media pandang, audio, dan visual) untuk melengkapi penyampaian materi pembelajaran.

3. Bila merasa tepat gunakan humor dalam proses pembelajaran.

4. Gunakan peristiwa nyata, dan contoh-contoh untuk memperjelas konsep yang digunakan.

5. Gunakan teknik bertanya untuk melibatkan siswa.

B. Relevance (relevan)

Relevance yang dimaksud di sini dapat diartikan sebagai keterkaitan atau kesesuaian antara materi pembelajaran yang disajikan dengan pengalaman belajar siswa. Dari keterkaitan atau kesesuaian ini otomatis dapat menumbuhkan motivasi belajar di dalam diri siswa karena siswa merasa bahwa materi pelajaran yang disajikan mempunyaai manfaat langsung secara pribadi dalam kehidupan sehari-hari siswa. Motivasi siswa akan bangkit dan berkembang apabila mereka merasakan bahwa apa yang dipelajari itu 
memenuhi kebutuhan pribadi, bermanfaat serta sesuai dengan nilai yang diyakini atau dipegangnya.

C. Confidence (percaya diri)

Menurut Keller (1987) strategi yang dapat digunakan untuk meningkatkan kepercayaan diri siswa adalah sebagai berikut:

1. Meningkatkan harapan siswa untuk berhasil dengan memperbanyak pengalaman siswa, misal dengan menyusun materi pembelajaran agar dengan mudah difahami, di urutkan dari materi yang mudah ke sukar. Dengan demikian, siswa merasa mengalami keberhasilan sejak awal proses pembelajaran.

2. Susunlah kegiatan pembelajaran ke dalam bagian-bagian yang lebih kecil, sehingga siswa tidak dituntut untuk mempelajari terlalu banyak konsep baru dengan sekaligus.

3. Meningkatkan harapan untuk berhasil, hal ini dapat dilakukan dengan menyampaikan tujuan pembelajaran dan kriteria tes pada awal pembelajaran. Hal ini akan membantu siswa mempunyai gambaran yang jelas mengenai apa yang diharapkan.

4. Meningkatkan harapan untuk berhasil dengan menggunakan strategi yang memungkinkan kontrol keberhasilan di tangan siswa sendiri.

5. Tumbuh kembangkan kepercayaan diri siswa dengan menganggap siswa telah memahami konsep ini dengan baik serta menyebut kelemahan siswa sebagai hal-hal yang masih perlu dikembangkan.

6. Berilah umpan balik yang relevan selama proses pembelajaran agar siswa mengetahui pemahaman dan prestasi belajar mereka sejauh ini

D. Satisfaction (kepuasan) 
Perasaan ini dapat meningkat kepada perasaan kepuasan diri siswa nantinya dengan membangkitkan semangat belajar diantaranya dengan:

1. Mengucapkan "baik", "bagus" dan seterusnya bila peserta didik menjawab / mengajukan pertanyaan.

2. Memuji dan memberi dorongan, dengan senyuman, anggukan dan pandangan yang simanatik atas partisipasi siswa.

3. Memberi tuntunan pada siswa agar dapat memberi jawaban yang benar.

4. Memberi pengarahan sederhana agar siswa memberi jawaban yang benar.

Ilmu Pengetahuan Sosial (IPS) adalah mata pelajaran yang mempelajari kehidupan sosial yang didasarkan pada bahan kajian geografi, ekonomi,sosiologi, antropologi, tata negara dan sejarah. IPS adalah istilah yang digunakan untuk menggambarkan penelitian dengan cakupan yang luas dalam berbagai lapangan yang meliputi perilaku dan interaksi manusia dimasa kini dan masa lalu. IPS tidak memusatkan diri pada satu topik secara mendalam melainkan memberi tinjauan yang luas terhadap masyarakat.

Dalam kurikulum Tingkat Satuan Pendidikan (KTSP) 2006 tercantum bahwa tujuan khusus pengajaran IPS disekolah dapat dikelompokkan menjadi empat komponen yaitu:

a. Memberikan kepada Siswa pengetahuan tentang pengalaman manusia dalam kehidupan bermasyarakat pada masa lalu, sekarang dan masa akan datang.

b. Menolong siswa untuk mengembangkan keterampilan (skill) untuk mencari dan mengolah informasi.

c. Menolong siswa untuk mengembangkan nilai / sikap demokrasi dalam kehidupan bermasyarakat. 
d. Menyediakan kesempatan kepada siswa untuk mengambil bagian / berperan serta dalam bermasyarakat.

Dalam penelitian ini, langkah-langkah pembelajaran dengan model ARCS adalah sebagai berikut. :

a. Mengingatkan kembali siswa pada konsep yang telah dipelajari

b. Menyampaikan tujuan dan manfaat pembelajaran (R)

c. Menyampaikan materi pelajaran (R)

d. Menggunakan contoh-contoh yang konkrit (A dan R)

e. Memberi bimbingan belajar (R)

f. Memberi kesempatan kepada siswa untuk berpartisipasi dalam pembelajaran (C dan $S$ )

g. Memberi umpan balik (S)

h. Menyimpulkan setiap materi yang telah disampaikan di akhir pembelajaran $(S)$

i. Peningkatan motivasi belajar siswa akan membantu guru dalam proses pembelajaran yaitu meningkatkan hasil belajar, melalui penerapan model pembelajaran ARCS guru bisa mengetahui seberapa besar motivasi belajar siswa dengan melihat seberapa jauh perhatian siswa dalam mengikuti pelajaran, seberapa jauh siswa merasakan ada kaitan atau relevansi pembelajaran dengan kebutuhannya, seberapa jauh siswa merasa yakin terhadap kemampuannya dalam mengerjakan tugas-tugas pembelajaran, serta seberapa jauh siswa merasa puas terhadap kegiatan belajar yang telah dilakukan, khususnya pada pembelajaran IPS. Pada umumnya ada beberapa indikator yang menunjukan motivasi belajar pada siswa meliputi: (1) adanya hasrat dan keinginan berhasil, (2) adanya dorongan dan kebutuhan dalam belajar, (3) adanya harapan dan cita-cita masa depan, (4) adanya penghargaan dalam belajar, (5) adanya kegiatan menarik dalam belajar, (6) 
adanya lingkungan yang kondusif sehingga memungkinkan seseorang dapat belajar dengan baik (Uno, 2010).

Motivasi keadaan psikologis atau fisiologis dalam diri pribadi seseorang yang mendorong individu untuk melakukan aktivitasaktivitas tertentu untuk mencapai tujuan . Herbert L. Petir (1981) mengatakan : "Motivasion is the concept we use when we decribel the forces acting on or within an organism to initiate an direct behavior."(Herbert, 1981)

Menurut Winkel, adalah keseluruhan daya penggerak psikis dari dalam diri siswa yang menimbulkan kegiatan belajar, menjamin kelangsungan belajar dan memberikan arahan pada kegiatan belajar itu demi mencapai suatu tujuan tertentu (Ws., 1989)

Beberapa indikator yang menunjukan motivasi belajar pada siswa meliputi:

(1) adanya hasrat dan keinginan berhasil,

(2) adanya dorongan dan kebutuhan dalam belajar,

(3) adanya harapan dan cita-cita masa depan,

(4) adanya penghargaan dalam belajar,

(5) adanya kegiatan menarik dalam belajar,

(6) adanya lingkungan yang kondusif sehingga memungkinkan seseorang dapat belajar dengan baik (Uno, 2010).

Berdasarkan pemaparan tersebut, hasil belajar dipengaruhi banyak faktor. Pemilihan model yang tepat akan mempengaruhi hasil belajar karena model pembelajaran akan menggambarkan langkah-langkah dan kegiatan pembelajaran, pengaturan lingkungan belajar yang nantinya sangat mempengaruhi hasil belajar. Selain itu, berpijak pada keunggulan model pembelajaran ARCS, maka diduga model pembelajaran ini akan berpengaruh terhadap hasil belajar siswa. Disamping pemilihan model 
pembelajaran yang tepat, motivasi belajar juga sangat mempengaruhi hasil belajar Motivasi belajar yang berbeda diduga akan memberikan hasil belajar yang berbeda pula.

Untuk itu penulis mencoba untuk mengkaji lebih jauh tentang model pembelajaran dengan memperhatikan motivasi belajar, sebagai sebuah inovasi dalam pengembangan pembelajaran melalui suatu kajian penelitian tentang Pengaruh Model Pembelajaran ARCS (Attention, Relevance, Confidence, Satisfaction.) dan motivasi terhadap hasil belajar IPS siswa Kelas V SD Negeri 75 Kota Bengkulu

\section{B. METODE}

penelitian ini menggunakan pendekatan Kuantitatif dengan Jenis penelitian Quasi Eksxperimen. yang menggunakan tiga variabel penelitian. Hasil belajar IPS sebagai variabel terikat, model pembelajaran, yang dibedakan menjadi dua kelompok, yaitu model pembelajaran ARCS (A1) dan model pembelajaran konvensional (A2) sebagai variabel bebas, dan motivasi belajar (B), yang dibedakan menjadi dua kelompok, yaitu motivasi belajar tinggi (B1) dan motivasi belajar rendah (B2) sebagai variabel mederator.

Teknik yang digunakan dalam pengambilan data adalah kuesioner tentang motivasi belajar dan tes dengan instrumen tes hasil belajar IPS untuk jenis data hasil belajar IPS. Adapun tiap - tiap instrumen dijabarkan terlebih dahulu konsep variable dan sub bariabel serta indikatornya, kemudian dilanjutkan dengan paparan berupa kisi - kisi yang digunakan untuk menyusun setiap instrumen yang yang diujicobakan dalam rangka uji validitas dan reliabilitasnya.

Adapun desain penelitiannya adalah sebagai berikut :

Tabel 1. Desain Penelitian Faktorial 2x2 


\begin{tabular}{|l|l|l|}
\hline $\begin{array}{l}\text { Variabel Atribut } \\
\text { (Motivasi Belajar }\end{array}$ & \multicolumn{2}{|l|}{$\begin{array}{l}\text { Model Pembelajaran } \\
(\text { X1) }\end{array}$} \\
\cline { 2 - 3 } (X2) & $\begin{array}{l}\text { Model Pembelajaran } \\
\text { ARCS (A1) }\end{array}$ & $\begin{array}{l}\text { Model Pembelajaran } \\
\text { Konvesional (A2) }\end{array}$ \\
\hline $\begin{array}{l}\text { Motivasi Belajar } \\
\text { Tinggi (B1) }\end{array}$ & A1B1 & A2B1 \\
\hline $\begin{array}{l}\text { Motivasi Belajar } \\
\text { Rendah(B2) }\end{array}$ & A1B2 & A2B2 \\
\hline
\end{tabular}

\section{HASIL DAN PEMBAHASAN}

Skor hasil belajar siswa pada mata pelajaran IPS SD Negeri 75 kota Bengkulu setelah diberi perlakuan dengan model pembelajaran ARCS memperoleh hasil belajar yang berbeda dengan kelompok siswa yang diajar dengan menggunakan model pembelajaran konvensioanl sebagaimana yang ditunjukkan pada tabel 2 berikut ini

Tabel 2. Skor hasil bel;ajar siswa pada kelompok Eksperimen (A1) dan Kelompok Kontrol (A2)

\begin{tabular}{|l|l|l|l|}
\hline $\begin{array}{r}\text { Model } \\
\text { Pembelajaran } \\
\text { (A) }\end{array}$ & $\begin{array}{l}\text { Pembelajaran } \\
\text { ARCS }\end{array}$ & $\begin{array}{l}\text { Pembelajaran } \\
\text { Konvensional }\end{array}$ & Gain Skor \\
$\begin{array}{l}\text { Tingkat } \\
\text { Motivasi } \\
\text { (B) }\end{array}$ & 76.16 & 64.22 & 5.61 \\
\hline Keseluruhan & 77.11 & 60.89 & 16.22 \\
\hline Tinggi & 66.44 & 61.33 & 5.11 \\
\hline Rendah & & & \\
\hline
\end{tabular}

Tabel di atas menunjukkan, bahwa secara keseluruhan penggunaan model pembelajaran ARCS lebih efektif dari pada model pembelajaran konvensional dalam mempengaruhi hasil belajar siswa dalam mata pelajaran IPA. . Begitu juga jika dilihat dari tingkat motivasi belajar siswa tinggi, penggunaan model pembelajaran ARCS juga lebih efektif disbanding dengan model pembelajaran konvensional dalam 
mempengaruhi hasil belajar siswa. Namun jika dilihat dari tingkat motivasi belajar siswa rendah, dari segi rata ada perbedaan, namun setelah diuji dengan analisis statistic dengan uji “ $\mathrm{t}$ ” ternyata kedua model pembelajaran tidak ada perbedaan dalam mempengaruhi ,maka kedua model tersebut tidak ada perbedaan atau sama saja. Secara rinci akan dideskripsikan berikut ini.

1). Terdapat perbedaan hasil belajar siswa antara yang diajar dengan menggunakan model pembelajaran ARCS dengan model pembelajaran konvensional pada mata pelajaran IPS kelas V SD Negeri 75 kota Bengkulu. Hal ini dibuktikan dengan uji-t diperoleh nilai-t 5.471 dengan df 62 dan Sig. 0,000 (2-tailed). lebih kecil dari taraf signifikasi $5 \%(0,050)$

Model pembelajaran ARCS merupakan suatu bentuk pendekatan pemecahan masalah untuk merancang aspek motivasi serta lingkungan belajar dalam mendorong dan mempertahankan motivasi siswa untuk belajar. Hasil analisis data penelitian yang diperoleh melalui pengujian hipotesis pertama menunjukkan, bahwa secara keseluruhan model pembelajaran ARCS lebih tinggi dibanding dengan model pembelajaran konvensional . Hal ini sebabkan model pembelajaran ARCS adalah merupakan bentuk pembelajaran yang mengutamakan perhatian siswa, menyesuaikan materi pembelajaran dengan pengalaman belajar siswa, menciptakan rasa percaya diri dalam diri siswa dan menimbulkan rasa puas diri siswa tersebut, sehingga akan terjadi pembelajaran yang bermaknayakni sebuah model untuk meningkatkan motivasi dalam materi pembelajaran, yang mengandung empat komponen. Komponen- komponen Model ARCS yaitu: a). Attention (Perhatian), dimana dalam model ARCS berusaha untuk membangkitkan dan mempertahankan rasa ingin tahu peserta didik dan menarik minta siswa untuk belajar, b), Relevance, yakni dalam penerapannya selalu menghubungkan pembelajar kebutuhan, minat, dan motif, Confidence (kepercayaan), 
dalam penerapannya selalu berusaha mengembangkan harapan positif kepada siswa untuk mencapai kesuksesan dan tantangan bervariasi bagi peserta didik untuk mengalami kesuksesan, dan satisfactian.(kepuasan), yakni mendorong dan mendukung kepuasan intrinsik dari pengalaman belajar sswa melalui penghargaan.

Sementera model pembelajaran yang selama ini dilaksanakan sifatnya rutunitas dan berorientasi kepada penyelesaian tugas, sementara siswa masih terpaku pada apa yang didengar dan disuruh oleh guru, sehingga apa yang diterima siswa dalam proses pembelajaran bersifat hafalan semata. Bahkan aktivitas yang dilakukan siswa secara individu maupun secara kelompok belum menunjukkan adanya perhatian secara optimal, belum secara optimal menghubungan antara materi, metode dengan kebutuhan , minat, dan motivasi siswa, belum mengembangkan harapan positif bagi siswa, dan sering terabaikan untuk memberikan penghargaan kepada siswa,

2). Terdapat perbedaan hasil belajar siswa yang memiliki motivasi tinggi antara yang diajar dengan menggunakan Model ARCS dengan model konvensional pada mata pelajaran IPS siswa kelas V SD Negeri 75 Bengkulu .

Hasil analisis data penelitian yang diperoleh melalui pengujian hipotesis kedua ini sebesar nilai sig. $0 . .001<0.050$ menunjukkan bahwa hasil belajar siswa yang memiliki tingkat motivasi tinggi diajar dengan model pembelajaran ARCS (A1B1) lebih tinggi dari pada diajar dengan menggunakan model pembelajaran konvensional (A2B1) pada mata pelajaran IPS kelas V SD Negeri 75 kota Bengkulu.

- ARCS sebagai model pendekatan dalam pembelajaran dikembangkan oleh Keller dan Kopp (1987) sebagai jawaban pertanyaan "bagaimana merancang pembelajaran yang dapat mempengaruhi motivasi belajar dan hasil belajar". Model ARCS berakar pada banyak teori dan konsep motivasi, khasnya adalah teori harapan-nilai (expectancy-value). 
3). Tidak terdapat perbedaan hasil belajar siswa yang memiliki motivasi rendah antara yang diajar dengan menggunakan Model ARCS dengan model konvensional pada mata pelajaran IPS siswa kelas V SD Negeri 75 Begkulu

Hasil analisis data penelitian yang diperoleh melalui pengujian hipotesis ketiga ini sebesar nilai sig. $0.235>0.050$ menunjukkan bahwa hasil belajar siswa yang memiliki tingkat motivasi rendah diajar dengan model pembelajaran ARCS (A1B1) tidak berbeda (sama) dengan diajar menggunakan model pembelajaran konvensional (A2B1) pada mata pelajaran IPS kelas V SD Negeri 75 kota Bengkulu

Dari hasil penelitian membuktikan bahwa model ARCS yang selalu terkait dengan dengan motivasi siswa, tidak selamanya cocok untuk siswa yang memiliki tingkat motivasi rendah, khususnya pada siswa kelas V SD/MI. Tidak adanya perbedaan hasil belajar siswa yang memiliki tingkat motivasi rendah ini, karena banyak factor yang mempengaruhi di samping factor guru, oleh karena itu guru memerlukan metode yang dapat mengembangkan dan selalu berusaha untuk membangikitkan motivasi belajar siswa. Dengan motivasi yang tinggi maka dengan model ARCS akan mampu meningkatkan perhatian, minat, kepercayaan yang tinggi, dan kepuasan bagi siswa dalam mencapai hasil belajar yang tinggi .

4). Tidak terdapat interaksi antara model pembelajaran dan tingkat motivasi belajar siswa terhadap hasil belajar IPS siswq Kelas V SD Negeri 75 Bengkulu.

Berdasarkan hasil uji hipotesis keempat menujukkan tidak adanya interaksi antara model pembelajaran dengan motivasi belajar siswa terhadap kemampuan hasil belajar siswa pada mata pelajaran IPS. Hal ini dibuktikan dengan adanya hasil belajar siswa, baik secara keseluruhan maupun dilihat dari masing-masing tingkat motivasi belajar siswa yang diajar dengan menggunakan model ARCS dan model konvensional. Hasil analisis of varians (anova) dengan 
menggunakan SPSS untuk uji hipoteisis Faktor Interaksi (MPxTM) terhadap hasil belajar, menerima hipotesis Nol dan menolak hipotesis Alternative, yang berarti efek faktor model pembelajaran dan tingkat motivasi tidak terdapat interaksi terhadap hasil belajar siswa.

Hasil ini dibukikan dengan uji Anova diperoleh $\mathrm{Fh}<\mathrm{F}$ tabel (3.738< 4.11) / sig $0.490>0.05$, menunjukkan tidak terjadi interaksi antara model pembelajaran dengan tingkat motivasi belajar siswa secara gabungan terhadap hasil belajar siswa

Secara teoritis tidak terjadi interaksi antara model pembelajaran dan motivasi belajar siswa terhadap hasil belajar siswa, karena dua model pembelajaran ini memeliki keunggulan yang berbada dalam penggunaannya. Sehingga ada salah satu yang tidak berbada/sama, yakni jika dilihat dari tingkat motivasi belajar rendah. Sementara dilihat dari tingkat motivasi belajar tinggi terdapat perbedaan hasil belajar siswa dari kedua penerapan model pembelajaran, begitu juga secara keseluruhan terdapat hasil belajar siswa dari kedua model pembelajaran tanpa memperhatikan tingkat motivasi belajar siswa.

Berdasarkan hasil penelitian, hasil belajar IPS kelompok siswa yang mengikuti model pembelajaran ARCS lebih tinggi daripada hasil belajar IPS kelompok siswa yang mengikuti model pembelajaran konvensional. Hasil tersebut, sekaligus membuktikan bahwa terdapat pengaruh yang sangat signifikan penerapan model pembelajaran ARCS terhadap hasil belajar IPS kelas V SD Negeri 75 kota Bengkulu

\section{KESIMPULAN DAN SARAN}

Berdasarkan hasil-hasil pengujian hipotesis dan pembahasan dalam penelitian ini, maka dapat disimpulkan, bahwa secara umum model pembelajaran dan motivasi belajar adalah esensial dalam pencapaian hasil belajar yang dapat diuraikan dalam empat 
kesimpulan: i). Secara keseluruhan terdapat perbedaan hasil belajar siswa antara yang diajar dengan menggunakan model ARCS dengan model konvensional mata pelajaran IPS kelas V SD Negeri 75 kota Bengkulu . Hal ini dibuktikan dengan uji-t diperoleh nilai-t 2.25 dengan df $62>t$ Tabel 2.000 dan Sig. 0,000(2-tailed). lebih kecil dari taraf signifikasi $5 \%(0,050) ; 2)$. terdapat perbedaan hasil belajar siswa dengan tingkat motivasi belajar tinggi antara yang diajar dengan menggunakan model pembelajaran ARCS dengan model pembelajaran konvensional mata pelajaran IPS kelas V SD Negeri 75 kota Bengkulu.. Hal ini dibuktikan dengan uji-t diperoleh nilai-t $4.074>\mathrm{t}$ Tabel 2.110 dengan df 16 dan Sig. (2-tailed) 0.001. lebih kecil dari taraf signifikasi $5 \%(0,050) . ; 3)$. tidak terdapat perbedaan hasil belajar siswa dengan tingkat motivasi belajar rendah antara yang diajar dengan menggunakan model pembelajaran ARCS dengan model konvensional mata pelajaran IPS kelas V SD Negeri 75 kota Bengkulu. Hal ini dibuktikan dengan uji-t diperoleh nilai-t $1.233<2.00$ dengan df 16 dan Sig. (2-tailed) 0.235. Nilai Sig. (2-tailed) lebih besar dari taraf signifikasi $5 \%(0,050)$; 4) Tidak terdapat interaksi antara model pembelajaran dengan tingkat motivasi belajar terhadap hasil belajar siswa pada mata pelajaran IPS kelas V SD Negeri 75 kota Bengkulu. Hal ini dibuktikan dengan uji F melalui SPSS, bahwa hasil nilai Sig. $(2$-tailed $)=0.062>(0,050)$ dengan demikian tidak terdapat interaksi..

Tidak adanya interaksi antara model pembelajaran dan tingkat motivasi belajar terhadap hasil belajar ini menunjukkan bahwa ada salah satu yang tidak berbeda/sama yakni berkaitan dengan tingkat motivasi rendah.

Berdasarkan temuan penelitian, pembahasan, dan refleksi akademik terkait dengan beberapa teori sejenis, serta dengan mempertimbangkan karakteristik serta keunggulan yang dimiliki oleh model pembelajaran, maka dapat dirumuskan saran sebagai berikut: (1) bagi Guru, selaku pengembang dan pelaksana kurikulum pada 
tingkat persekolahan, hendaknya menyadari bahwa kurikulum dan pembelajaran IPS yang ada saat ini masih memerlukan berbagai terobosan dan alternatif perbaikan menuju terwujudnya kualitas proses dan produk pembelajaran yang bermakna dan berdaya guna secara maksimal. Model pembelajaran ARCS dapat dijadikan sebagai salah satu alternatif yang aplikatif, dengan pertimbangan bahwa model pembelajaran ini memberikan sejumlah solusi kepada guru, berkaitan dengan upaya meningkatkan pemahaman materi peserta didik, peningkatan aktivitas belajar peserta didik, yang akhirnya bermuara pada peningkatan motivasi belajar dan hasil belajar siswa, disamping itu model pembelajaran ini telah teruji mampu meningkatkan hasil belajar siswa pada mata pelajaran IPS, dan model pembelajaran ini telah teruji dapat memperluas sumber belajar dan akses informasi peserta didik, sehingga akan berimplikasi pada peningkatan hasil belajarnya secara signifikan. (2) Sehubunagn dengan model pembelajaran ARCS sangat efektif diterapkan untuk meningkatkan hasil belajar siswa pada mata pelajaran IPS, maka diperlukan upayaupaya strategis oleh guru sebagai pelaku pendidikan IPS agar pengenalan dan pendekatan tersebut bisa ditingkatkan. (3). Bagi kepala sekolah, selaku pengawas dan atasan guru, diharapkan dapat menjadikan model pembelajaran ARCS sebagai salah satu alternatif untuk memperbaiki kualitas proses dan produk pembelajaran IPS, dengan cara memotivasi dan memfasilitasi guru dalam menerapkan pendekatan tersebut, termasuk menjadikan model pembelajaran tersebut sebagai bahan kajian dalam pertemuan-pertemuan para kepala sekolah, sehingga pendekatan ini semakin luas dan tersosialisasikan secara penuh makna. (5) kepada peneliti yang berminat untuk memverifikasi hasil penelitian ini, hendaknya mengkomparatifkan model pembelajaran ARCS dengan model pembelajaran yang lain. 


\section{E. REFERENCES / DAFTAR PUSTAKA}

Agustriana, N. (2019). PENGARUH METODE EDUTAINMENT DAN IDENTITAS DIRI TERHADAP KETERAMPILAN SOSIAL ANAK. Al-Fitrah, 1(2), 216-228. Retrieved from http://ejournal.iainbengkulu.ac.id/index.php/alfitrah/article/vi ew $/ 1517$

Ahmad, K. (2011). Strategi Pembelajaran Berorientasi KTSP. Jakarta: PT. Prestasi pustakarya.

Arikunto, S. (2010). Manajemen Penelitian. Jakarta: Rineka Cipta

Burhan, N. dkk. (2009). Statistik Terapan Untuk Penelitian Ilmu-Ilmu Sosial, Yogyakarta: Gadjah Mada

Buku: Motivational Design For Learning And Performance: The ARCS Model Approach Posted on Juni 15, 2013 by zulrahmattogala diunduh tanggal 12 Juli 2017

Dimyati dan Mujiono, http://eprints.uny.ac.id/9829/2/bab2.pdf (02-02-2017)

Uno, H. B. (2010). Teori motivasi dan pengukurannya. Jakarta: Bumi Aksara

https://learningtheori.wordpress.com/2010/03/08/model-arcs-keller// diunduh pada tanggal 10 Juni 2017

Imron, A. (1996). Belajar dan Pembelajaran. Jakarta: Pustaka Jaya .

Keller, J. M. 1987 https://zultogalatp.wordpress.com/2013/06/15/bukumotivational-design-for-learning-and-performance-the-arcsmodel-approach/diunduh pada tanggal 06 Juni 2017

Kurniah, N., Andreswari, D., \& Kusumah, R. G. T. (2019). Achievement of Development on Early Childhood Based on National Education Standard. In Proceedings of the International Conference on Educational Sciences and Teacher Profession (ICETeP 2018) (pp. 351354). Paris, France: Atlantis Press. https://doi.org/10.2991/icetep$\underline{18.2019 .82}$

Kusumah, R. G. T. (2019). Peningkatan Kemampuan Berfikir Kritis Mahasiswa Tadris IPA Melalui Pendekatan Saintifik Pada Mata kuliah IPA Terpadu. IJIS Edu: Indonesian Journal of Integrated Science Education, 1(1), 71-84. Retrieved from 
http://ejournal.iainbengkulu.ac.id/index.php/ijisedu/article/vie $\underline{\mathrm{w} / 1762}$

Kusumah, R. G. T., \& Munandar, A. (2017). Analysis Of The Relationship Between Self Efficacy And Healthy Living Conciousness Toward Science Learning Outcome. EDUSAINS, 9(2), 132-138. https:// doi.org/10.15408/ES.V9I2.2183

Lasmawan. (2010). Menelisik Pendidikan IPS dalam Persepektif KontekstualEmpirik. Singaraja: Mediakom Indinesia Press Bali.

Hasbullah, I. (2009). Dasar-Dasar Ilmu Pendidikan. Jakarta: PT Raja Grafindo Persada

Nurgiyantoro. (2010). Teori Pengkajian Fiksi. Yogyakarta: Gajah Mada University Press.

Petri, H. L. ( 1981). Motivation Teori And Research. California: Wadwarth publising Compani

Sapri, J., Agustriana, N., \& Kusumah, R. G. T. (2019). The Application of Dick and Carey Learning Design toward Student's Independence and Learning Outcome. In Proceedings of the International Conference on Educational Sciences and Teacher Profession (ICETeP 2018) (pp. 218-222). Paris, France: Atlantis Press. https://doi.org/10.2991/icetep-18.2019.53

Sari, R. P., Suryani, N. A., \& Imran, R. F. (2018). PENINGKATAN KEMAMPUAN MEMBACA PERMULAAN DENGAN MENGGUNAKAN METODE BERMAIN FLASH CARD SUBACA DI PAUD AL-ANISA BENTIRING KOTA BENGKULU. Jurnal AlAthfaal, 1(2), 36-55.

Sudjana, N. (2011). Penilaian Hasil Proses Belajar Mengajar. Bandung: Remaja Rosdakarya,

Suyanto. (2008). Pendidikan Agama Islam. Klaten: CV.Sahabat klaten

Trianto. (2010). Model Pembelajaran Terpadu. Jakarta: PT Bumi Aksara.

Teller, Motivational Design For Learning And Performance: The ARCS Model ApproachPosted on Luni 15, 2013 by zulrahmattogala

Winkel, W.S. ( 1987). Psikologi Pengajaran. Jakarta: Gramedia 
Yaba. (2006). Ilmu Pengetahuan Sosial 1. Makassar: Fakultas Ilmu Pendidikan Universitas Negeri Makassar. 